\title{
Rates of rumen fermentation in relation to ammonia concentration
}

\author{
By A. Z. MEHREZ*, E. R. ØRSKOV AND I. MCDONALD \\ Rowett Research Institute, Bucksburn, Aberdeen AB2 $9 S B$
}

(Received 30 November 1976 - Accepted 7 April 1977)

\begin{abstract}
1. Four sheep were fed from automatic continuous feeders on whole barley fortified with graded levels of a urea solution. This approach was to a large extent successful in maintaining relatively steady states of rumen ammonia concentration.

2. Rates of barley fermentation in the rumen at various rumen $\mathrm{NH}_{3}$ concentrations were assessed by measuring the disappearance of barley dry matter from polyester bags suspended in the rumen of these sheep.

3. The minimal $\mathrm{NH}_{3}$ concentration for maximal rate of fermentation was estimated as $235 \mathrm{mg} / \mathrm{l}$ rumen fluid.
\end{abstract}

The optimal ammonia concentration of rumen fluid may be defined as that which results either in the maximum rate of fermentation in the rumen or that which allows the maximum production of microbial protein per unit of substrate fermented. The two definitions may not always coincide; for instance Ørskov, Fraser \& McDonald (1972) showed with a barley feed that the microbial protein produced per unit of substrate fermented was not altered as a result of urea supplementation while the extent of rumen fermentation and digestibility was increased.

The rate at which rumen fermentation proceeds has a great influence on both total and digestible feed intakes (Balch \& Campling, 1962) and therefore feed intake may be reduced if $\mathrm{NH}_{3}$ concentration is limiting the rate of fermentation.

Diurnal variation in all constituents of rumen fluid, generally associated with the time of feeding, make it difficult to estimate optimal rumen $\mathrm{NH}_{3}$ concentration. A steady state of rumen fermentation can be achieved by continuous feeding. Although urea can also be infused continuously, its absorption into grains (Ørskov, Smart \& Mehrez, 1974) offers another simple method for stabilizing rumen $\mathrm{NH}_{3}$ concentration.

The use of the 'polyester bag' technique (Mehrez \& Ørskov, 1977) enabled us to determine rapidly and accurately the rate of substrate fermentation in the rumen.

This present experiment was carried out to investigate the relationship between rumen $\mathrm{NH}_{3}$ concentration and rate of fermentation.

A brief account of this work has been published (Mehrez \& Ørskov, 1976).

\section{MATERIALS AND METHODS}

Animals. The four sheep used consisted of three Suffolk $\times$ (Finnish Landrace $\times$ Dorset Horn) and one Cheviot. They were approximately 6-8 months of age and weighed $35-40 \mathrm{~kg}$. Each animal was fitted with a rumen cannula $40 \mathrm{~mm}$ in diameter. During recovery from the operation, the animals were trained to receive their diet from an automatic continuous feeder. They had completely recovered and were well accustomed to the feeding system 3-4 weeks after the operation, and they were then allocated to the experimental treatments.

Experimental. Whole barley containing $20.9 \mathrm{~g}$ nitrogen $/ \mathrm{kg}$ dry matter (DM) was used as a basal diet. It was given either unfortified or fortified with increments of $2-10 \mathrm{~g} u r e a / \mathrm{kg}$ barley to constitute the six experimental diets. Each increment of $2 \mathrm{~g}$ urea $/ \mathrm{kg}$ barley grains

* Present address: Faculty of Agriculture, University of Mansoura, El-Mansoura, Egypt. 
Table 1. The sequence of feeding for four sheep given six experimental diets which consisted of barley grains supplemented with graded levels of urea*

\begin{tabular}{crrrr} 
& \multicolumn{4}{c}{$\begin{array}{c}\text { Experimental diet } \\
\text { (g urea/kg) }\end{array}$} \\
\cline { 2 - 5 } $\begin{array}{c}\text { Sheep ... } \\
\text { Experimental } \\
\text { period no. }\end{array}$ & A & B & C & D \\
1 & & & & \\
2 & 2 & 8 & 8 & 2 \\
3 & 4 & 6 & 6 & 4 \\
4 & 6 & 4 & 4 & 6 \\
5 & 8 & 2 & 2 & 8 \\
6 & 10 & 0 & 0 & 10 \\
7 & 0 & - & - & 0 \\
* For details of diets, see below.
\end{tabular}

resulted in increasing the $\mathrm{N}$ content of the grains on average by $1 \cdot 1 \mathrm{~g} \mathrm{~N} / \mathrm{kg} \mathrm{DM}$. The four sheep (A, B, C and D) were given the diets according to the sequence shown in Table 1.

Feeding and management. The sheep were kept in individual pens and each was fed from an individual continuous feeder. The absorption method described by Ørskov, Smart \& Mehrez (1974) was used for fortifying the barley grains not only with urea but also with minerals and vitamins $\left(\mathrm{g} / \mathrm{kg}\right.$ diet; $12 \mathrm{CaCl}_{2}, 4 \mathrm{Na}_{2} \mathrm{O}_{4}, 1.25$ trace minerals and vitamins). The trace minerals and vitamins supplement contained the same ingredients as that used by Ørskov et al. (1972).

The procedure used to incorporate urea and the supplement in the barley was as follows: (1) the barley was veighed and placed in a vertical mixer; (2) the required amount of $\mathrm{CaCl}_{2}$ was dissolved in water $(1: 3, \mathrm{w} / \mathrm{v})$ at $40-50^{\circ}$; (3) urea was dissolved in the $\mathrm{CaCl}_{2}$ solution and then sprayed on the barley while the mixer was running. Mixing was continued for a minimum of $10 \mathrm{~min}$ before the addition of the next ingredient; (4) the trace minerals and vitamins mixture was mixed with water $(1: 3, \mathrm{w} / \mathrm{v})$. This was added slowly to the barley in the mixer, and mixing continued for an additional $10 \mathrm{~min}$; (5) finally, the $\mathrm{Na}_{2} \mathrm{SO}_{4}$ was dissolved in water $(1: 3, \mathrm{w} / \mathrm{v})$ and added gradually to the barley, and mixing was continued for another $10 \mathrm{~min}$.

Every animal received $1 \mathrm{~kg}$ of each diet/d for 1 week except when urea was not included, in which situation the sheep were offered the diet for 3 weeks. Illumination was maintained during the night to allow eating.

On each of the last $2 \mathrm{~d}$ of each period, four Polyester bags (Mehrez \& Ørskov, 1977) containing a known amount of rolled barley DM (approximately $4.3 \mathrm{~g}$ ) were incubated in the rumen of each sheep, being placed there at the same time of day ( 09.00 hours). One bag was removed after $1 \cdot 5,3,6$ and $9 \mathrm{~h}$ of incubation. Rumen fluid samples were obtained from each sheep initially and at the end of each incubation interval. The samples were obtained by gentle suction from different positions in the rumen. They were strained through a double layer of surgical gauze, frozen immediately and stored at $-20^{\circ}$ until they were analysed for $\mathrm{NH}_{3}$ concentration.

After removal from the rumen, the bags were washed and dried to constant weight as described by Mehrez \& Ørskov (1977) to determine DM disappearance.

Analytical methods. N content of the barley was determined by the automated Kjeldahl method described by Davidson, Mathieson \& Boyne (1970). Rumen $\mathrm{NH}_{3}$ concentration was determined by the method of Whitehead, Cooke \& Chapman (1967). 
Statistical methods. The relationship between DM disappearance $(y ; \mathrm{g}$ DM disappearing $/ \mathrm{kg}$ incubated) and rumen $\mathrm{NH}_{3}$ concentration ( $x ; \mathrm{mg} / \mathrm{l}$ rumen fluid) was initially described by an exponential model $y=\mathrm{A}+\mathrm{B} e^{-c x}$ where $\mathrm{A}, \mathrm{B}$ and $\mathrm{C}$ are constants. Equations of this form were fitted separately to the results for incubation intervals of $1.5,3,6$ and $9 \mathrm{~h}$, using the mean values over the two days of measurement. The fitted curves are shown in Fig. 1 together with the individual values from which they were obtained. It is evident that in the central range of $\mathrm{NH}_{3}$ concentrations most of the points lie above the curves, and it appears that the curves approach their asymptotic values too gradually to agree with the results.

Because of the doubtful fit of the exponential model a second one was tested which assumes that as $\mathrm{NH}_{3}$ concentration is increased the DM disappearance approaches a maximum value linearly rather than asymptotically. This may be described as the 'plateau' model, defined by two equations:

$$
\begin{array}{ll}
y=a+b x & \text { for } x<x_{1} \\
y=c \quad\left(\text { where } c=a+b x_{1}\right) & \text { for } x>x_{1}
\end{array}
$$

where $y$ and $x$ are as before, $x_{1}$ is the estimated optimal $\mathrm{NH}_{3}$ concentration above which there was no additional DM disappearance, and $a, b$ and $c$ are constants. In fitting the model to the data a possible value was chosen for $x_{1}$, and the constants $a, b$ and $c$ were estimated by least-square methods, subject to the constraint that $c=a+b x_{1}$. The procedure was repeated for a series of values of $x_{1}$ within the possible range, and the best estimate was taken to be that which resulted in the best fit to the results. The final lines are shown in Fig. 1 and are clearly more consistent with the results than are the exponential curves.

\section{RESULTS}

The animals always consumed the feed available from the automatic feeders as soon as the grains fell into the troughs.

\section{Stability of rumen $\mathrm{NH}_{3}$ concentration}

The mean $\mathrm{NH}_{3}$ concentrations achieved at different levels of urea supplementation for five samples taken during the $2 \mathrm{~d}$ of sampling in each experimental period are presented in Table 2. It was apparent from the low standard deviation that the continuous feeding of barley grains supplemented with urea by the absorption method was to a large extent successful in maintaining a reasonably steady-state of $\mathrm{NH}_{3}$ concentration, and there were no indications of variation associated with time of sampling.

\section{Rate of barley fermentation in relation to $\mathrm{NH}_{3}$ concentration in the rumen}

Rates of rumen fermentation as determined by proportions of $D M$ disappearing from the bags relative to the $\mathrm{NH}_{3}$ concentration in the rumen are shown in Fig. 1 (mean values over 2 d).

Increasing the $\mathrm{NH}_{3}$ concentration by increasing the level of urea resulted in an increase in the proportion of DM disappearance up to a maximum associated with each incubation period.

It seemed from the values shown in Fig. 1 that the DM disappearance was either 'flattening off' exponentially or was increasing linearly up to a maximum after which it remained nearly constant with increasing $\mathrm{NH}_{3}$ concentration.

\section{Estimation of the $\mathrm{NH}_{3}$ concentration necessary for maximum rate of fermentation in the rumen}

It is clear from Fig. 1 that the minimal $\mathrm{NH}_{3}$ concentration $\left(x_{1}\right)$ necessary for maximal DM disappearance was within the range of $200-270 \mathrm{mg} / 1$ rumen fluid. A series of values of $x_{1}$ 
Table 2. The effect of continuous feeding of barley grains supplemented with graded levels of urea* to sheep on diurnal rumen ammonia concentrations

(Mean values and standard deviations for sets of five observations)

\begin{tabular}{|c|c|c|c|c|c|}
\hline \multirow{3}{*}{\multicolumn{2}{|c|}{$\begin{array}{c}\text { Level of } \\
\text { urea } \\
\text { supplementation } \\
\text { Sheep } \quad \text { (g/kg diet) }\end{array}$}} & \multicolumn{4}{|c|}{$\mathrm{NH}_{3}$ concentration (mg/l rumen fluid) } \\
\hline & & \multicolumn{2}{|c|}{ Day 1} & \multicolumn{2}{|c|}{ Day 2} \\
\hline & & Mean & SD & Mean & SD \\
\hline $\mathbf{A}$ & $\begin{array}{r}0 \\
2 \\
4 \\
6 \\
8 \\
10 \\
0\end{array}$ & $\begin{array}{r}77 \\
135 \\
214 \\
253 \\
309 \\
375 \\
129\end{array}$ & $\begin{array}{r}4.5 \\
10.0 \\
20.5 \\
1.9 \\
3.6 \\
26.5 \\
16.6\end{array}$ & $\begin{array}{r}52 \\
158 \\
181 \\
205 \\
304 \\
564 \\
150\end{array}$ & $\begin{array}{r}4.3 \\
4.4 \\
16.4 \\
9.5 \\
12.8 \\
28.5 \\
7.9\end{array}$ \\
\hline B & $\begin{array}{r}0 \\
2 \\
4 \\
6 \\
8 \\
10\end{array}$ & $\begin{array}{r}81 \\
152 \\
200 \\
269 \\
382 \\
360\end{array}$ & $\begin{array}{r}0 \cdot 7 \\
2 \cdot 8 \\
28 \cdot 1 \\
20 \cdot 3 \\
24 \cdot 4 \\
42 \cdot 2\end{array}$ & $\begin{array}{r}74 \\
179 \\
215 \\
246 \\
299 \\
356\end{array}$ & $\begin{array}{r}3 \cdot 1 \\
4 \cdot 3 \\
24 \cdot 4 \\
15 \cdot 7 \\
33 \cdot 2 \\
11 \cdot 2\end{array}$ \\
\hline C & $\begin{array}{r}0 \\
2 \\
4 \\
6 \\
8 \\
10\end{array}$ & $\begin{array}{r}76 \\
129 \\
235 \\
250 \\
341 \\
330\end{array}$ & $\begin{array}{r}4 \cdot 4 \\
11 \cdot 2 \\
8.9 \\
25 \cdot 6 \\
12 \cdot 2 \\
59 \cdot 8\end{array}$ & $\begin{array}{r}71 \\
149 \\
204 \\
328 \\
302 \\
445\end{array}$ & $\begin{array}{r}6.9 \\
\frac{1}{13 \cdot 8} \\
25 \cdot 1 \\
7.9 \\
38.8\end{array}$ \\
\hline $\mathrm{D}$ & $\begin{array}{r}0 \\
2 \\
4 \\
6 \\
8 \\
10 \\
0\end{array}$ & $\begin{array}{r}104 \\
151 \\
192 \\
207 \\
219 \\
283 \\
74\end{array}$ & $\begin{array}{r}15 \cdot 6 \\
16 \cdot 1 \\
6 \cdot 0 \\
6 \cdot 4 \\
25 \cdot 4 \\
43 \cdot 2 \\
6 \cdot 2\end{array}$ & $\begin{array}{r}128 \\
179 \\
145 \\
216 \\
252 \\
268 \\
72\end{array}$ & $\begin{array}{r}9 \cdot 9 \\
9 \cdot 5 \\
1 \cdot 5 \\
7 \cdot 3 \\
4 \cdot 7 \\
43 \cdot 3 \\
5.7\end{array}$ \\
\hline
\end{tabular}

* For details of diets, see p. 437.

within this range were therefore used in fitting the 'plateau' model to the results for each incubation interval. The residual standard deviations (RSD) of the fitted equations are presented in Table 3. The estimate of $x_{1}$ which gave the lowest values of RSD was $235 \mathrm{mg} / \mathrm{l}$ rumen fluid, and this is therefore our estimate of the minimal $\mathrm{NH}_{3}$ concentration for maximum DM disappearance. The equations fitted to the values for each incubation interval were as follows:

Incubation interval for $x<235$ for $x>235$

(h)

$$
\begin{array}{lll}
1.5 & y=0.52 x+29 & y=151 \\
3 & y=1.26 x+52 & y=348 \\
6 & y=1.89 x+44 & y=488 \\
9 & y=1.86 x+168 & y=605
\end{array}
$$

From Table 3 it can be seen that $x_{1}$ could be varied between 230 and $240 \mathrm{mg} \mathrm{NH}_{3} / 1$ rumen fluid with very little change in the quality of fit of the 'plateau' model to the results, but that values as low as 210 or as high as $270 \mathrm{mg} / \mathrm{l}$ fitted substantially less well, the RSD's being increased by over $10 \%$ and the residual variances, therefore, by over $20 \%$. 


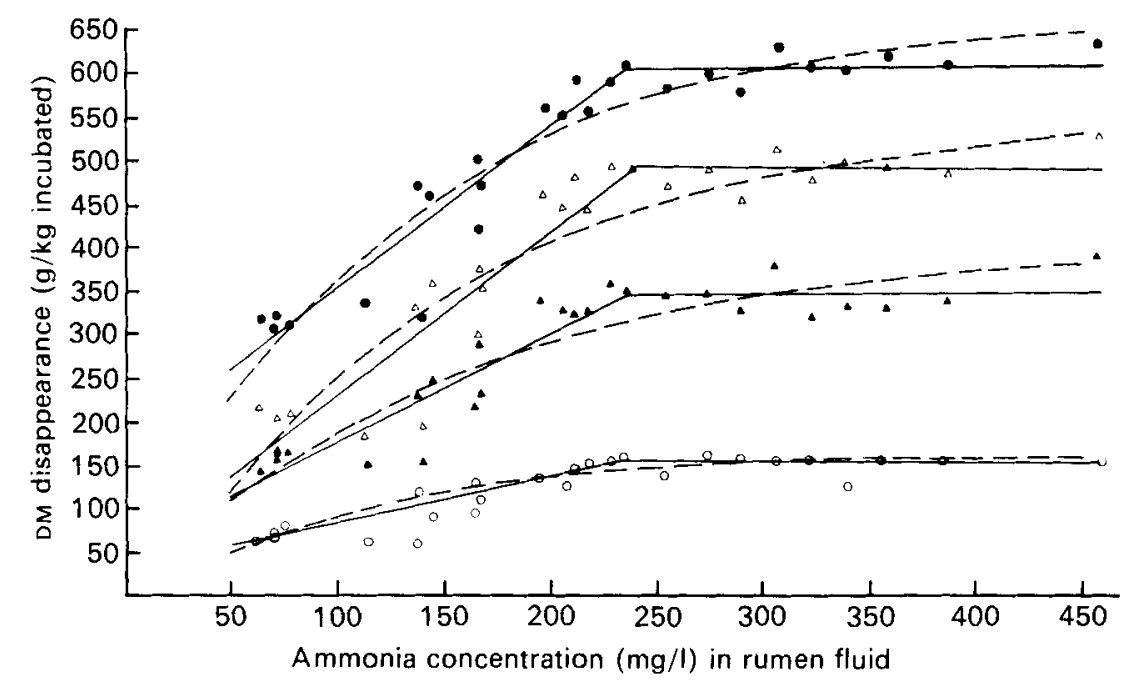

Fig. 1. The relationship between rumen ammonia concentration and the disappearance of dry matter of barley from Dacron bags incubated in the rumen of sheep for $1.5 \mathrm{~h}(O), 3 \mathrm{~h}(\Delta), 6 \mathrm{~h}(\triangle)$, $9 \mathrm{~h} \mathrm{( \bullet )} \mathrm{(for} \mathrm{experimental} \mathrm{details} \mathrm{see} \mathrm{p.} \mathrm{438).} \mathrm{(}--()$, exponential model; ( - ), 'plateau' model. (For details of equations see p. 439.) The results plotted are the means for two incubation days.

Table 3. The residual standard deviations of dry matter (DM) disappearance (y;g DM disappearing/ $\mathrm{kg}$ incubated) according to the exponential model and also according to the 'plateau' model for different assumed optimal values $\left(\mathrm{x}_{1}\right)$ of ammonia concentration $(\mathrm{x} ; \mathrm{mg} / \mathrm{l}$ rumen fluid) in the rumen of sheep fitted with Dacron bags containing a known amount of barley DM

\begin{tabular}{|c|c|c|c|c|}
\hline & \multicolumn{4}{|c|}{ Incubation interval (h) } \\
\hline & $1 \cdot 5$ & 3 & 6 & 9 \\
\hline \multicolumn{5}{|c|}{ Exponential model $\left(y=\mathrm{A}+\mathrm{B} e^{-\mathrm{C} x}\right)^{*}$} \\
\hline & $16 \cdot 3$ & $37 \cdot 9$ & $48 \cdot 3$ & $39 \cdot 4$ \\
\hline \multicolumn{5}{|c|}{$\begin{array}{l}\text { 'Plateau' model }\left(y=a+b x \text { for } x<x_{1} ; y=a+b x_{1} \text { for }\right. \\
\text { Assumed value } \\
\text { of } x_{1}\end{array}$} \\
\hline $\begin{array}{l}210 \\
220 \\
230 \\
235 \\
240 \\
250 \\
260 \\
270\end{array}$ & $\begin{array}{l}15.4 \\
14.5 \\
14.0 \\
13.9 \\
13.9 \\
14.2 \\
14.6 \\
14.9\end{array}$ & $\begin{array}{l}35 \cdot 2 \\
33 \cdot 5 \\
32 \cdot 3 \\
32 \cdot 3 \\
32 \cdot 4 \\
33 \cdot 2 \\
34 \cdot 4 \\
35 \cdot 7\end{array}$ & $\begin{array}{l}44 \cdot 9 \\
42 \cdot 4 \\
40 \cdot 7 \\
40 \cdot 5 \\
40 \cdot 7 \\
41 \cdot 7 \\
33 \cdot 4 \\
45 \cdot 3\end{array}$ & $\begin{array}{l}39 \cdot 4 \\
36 \cdot 7 \\
34 \cdot 7 \\
34 \cdot 1 \\
34 \cdot 0 \\
34 \cdot 6 \\
36 \cdot 1 \\
37 \cdot 7\end{array}$ \\
\hline
\end{tabular}

The RSD's of the exponential model are also given in Table 3 and are about $17 \%$ higher than the corresponding minimum values for the 'plateau' model, indicating a substantially inferior fit to the results.

\section{DISCUSSION}

It might have been possible to maintain steady $\mathrm{NH}_{3}$ levels in the rumen by continuous feeding of a basal diet and continuous infusion of urea solution into the rumen. The continuous feeding of barley grains supplemented with urea solution by the 'absorption' 
Table 4. Absolute (A $\mathrm{g} / \mathrm{kg}$ incubated) and relative $(R)$ proportions of maximal disappearance as predicted from the plateau model ${ }^{*}$ for dry matter (DM) disappearance at various levels of ammonia concentration in the rumen of sheep fitted with Dacron bags containing a known amount of barley DM

\begin{tabular}{|c|c|c|c|c|c|c|}
\hline \multirow{2}{*}{$\begin{array}{l}\text { Incubation } \\
\text { interval } \\
\text { (h) }\end{array}$} & \multirow{2}{*}{ Values } & \multicolumn{5}{|c|}{ Rumen ammonia (mg/l of rumen fluid) } \\
\hline & & 50 & 100 & 150 & 200 & $\geqslant 235$ \\
\hline $1 \cdot 5$ & $\begin{array}{l}\mathrm{A} \\
\mathrm{R}\end{array}$ & $\begin{array}{l}55 \\
0.36\end{array}$ & $\begin{array}{l}81 \\
0.54\end{array}$ & $\begin{array}{l}107 \\
0.71\end{array}$ & $\begin{array}{l}133 \\
0.88\end{array}$ & $\begin{array}{l}151 \\
1 \cdot 00\end{array}$ \\
\hline 3 & $\begin{array}{l}\mathbf{A} \\
\mathrm{R}\end{array}$ & $\begin{array}{l}115 \\
0.33\end{array}$ & $\begin{array}{l}178 \\
0.51\end{array}$ & $\begin{array}{l}241 \\
0.69\end{array}$ & $\begin{array}{l}304 \\
0.87\end{array}$ & $\begin{array}{l}348 \\
1.00\end{array}$ \\
\hline 6 & $\begin{array}{l}\mathbf{A} \\
\mathrm{R}\end{array}$ & $\begin{array}{l}139 \\
0.28\end{array}$ & $\begin{array}{l}232 \\
0.48\end{array}$ & $\begin{array}{l}328 \\
0.67\end{array}$ & $\begin{array}{l}422 \\
0.86\end{array}$ & $\begin{array}{l}488 \\
1.00\end{array}$ \\
\hline 9 & $\begin{array}{l}\mathbf{A} \\
\mathrm{R}\end{array}$ & $\begin{array}{l}261 \\
0.43\end{array}$ & $\begin{array}{l}354 \\
0.58\end{array}$ & $\begin{array}{l}447 \\
0.74\end{array}$ & $\begin{array}{l}540 \\
0.89\end{array}$ & $\begin{array}{l}605 \\
1.00\end{array}$ \\
\hline Mean & $\mathbf{R}$ & 0.35 & 0.53 & $0 \cdot 70$ & 0.88 & $1 \cdot 00$ \\
\hline
\end{tabular}

method resulted in fairly constant levels of rumen $\mathrm{NH}_{3}$ concentration. This approach avoided technical problems associated with continuous infusion of urea into the rumen.

Once microbial needs for $\mathrm{N}$ are met no further increase in rate of fermentation would be expected (Ørskov, Fraser \& McDonald, 1974). The point at which the response in rate of fermentation 'levels off' should indicate the minimal $\mathrm{NH}_{3}$ concentration for maximal rate of fermentation. The minimal $\mathrm{NH}_{3}$ concentration predicted by the 'plateau' model was $235 \mathrm{mg} / \mathrm{l}$ rumen fluid. The 'plateau' model fitted the values better than the exponential model for any incubation interval as shown in Table 3. The 'plateau' model had the further advantage for giving a direct estimate of the optimal $\mathrm{NH}_{3}$ concentration. Any estimate of the optimum from the exponential model necessarily involves an arbitrary decision on when the DM disappearance may be considered sufficiently near to its asymptotic value.

The predicted optimal level of $\mathrm{NH}_{3}$ concentration for maximal rate of fermentation was very high in comparison to most published values for optimal $\mathrm{NH}_{3}$ concentration for maximal microbial protein synthesis per unit of substrate fermented. For example, several studies made in vitro have shown that the $\mathrm{NH}_{3}$ concentration required for maximal microbial protein synthesis per unit of substrate fermented is approximately $50-60 \mathrm{mg} / \mathrm{l}$ rumen fluid (Bryant \& Robinson, 1961; Henderson, Hobson \& Summers, 1969; Allison, 1970; Satter \& Slyter, 1974). Studies made in vivo are usually preferable and have shown that the corresponding $\mathrm{NH}_{3}$ concentration is 88-133 (Hume, Moir \& Somers, 1970) or $289 \mathrm{mg} / \mathrm{l}$ rumen fluid (Miller, 1973). The high value reported by Miller (1973) is difficult to comment on since details of the experimental procedure used to derive it have not been described.

When $\mathbf{N}$ is not limiting to microbial growth there is good evidence to suggest that the amount of microbial protein synthesized is directly related to the amount of substrate fermented (Hungate, 1966). As far as the host animal is concerned, the rate at which substrate is fermented in the rumen has an important bearing on its voluntary intake.

The results of this experiment (Fig. 1) indicated that when $\mathrm{NH}_{3}$ concentration in the rumen was less than $235 \mathrm{mg} / \mathrm{l}$ rumen fluid the fermentation proceeded at less than maximal rate. The critical rumen $\mathrm{NH}_{3}$ concentration is that which is associated with a certain rate of fermentation which does not result in a high gut fill and consequently in a reduced voluntary food intake. 
In an attempt to illustrate the effect of $\mathrm{NH}_{3}$ concentration on rate of fermentation, the DM disappearance at various levels of rumen $\mathrm{NH}_{3}$ concentration was predicted from the 'plateau' model equations. Beyond the optimum $\mathrm{NH}_{3}$ concentration $(235 \mathrm{mg} / \mathrm{l}$ rumen fluid), the DM disappearance would be maximal. The predicted values are presented in Table 4.

It appears that under practical feeding conditions the $\mathrm{NH}_{3}$ concentration in the rumen need not be 235 or more $\mathrm{mg} / \mathrm{l}$ rumen fluid at all times since this concentration is only necessary for maximal rate of fermentation. With high-quality feeds of a low particle size, however, $\mathrm{NH}_{3}$ concentrations giving less than maximal rate of fermentation may result in reductions in digestibility.

Finally, the optimal $\mathrm{NH}_{3}$ concentration for maximal rate of fermentation of roughage diets might be different from that recorded in this study for barley, since it might be dependent on the prevalent $\mathrm{pH}$ conditions and on the availability of energy-yielding substrate. While the $\mathrm{pH}$ was not measured here previous experience would indicate that with feeding of whole grain to sheep the $\mathrm{pH}$ would normally be in the range from $6 \cdot 0-6 \cdot 2$. This aspect is at present being investigated.

\section{REFERENCES}

Allison, M. J. (1970). In Physiology of Digestion and Metabolism in the Ruminant, p. 456 [A. T. Phillipson, editor]. Newcastle upon Tyne: Oriel Press.

Balch, C. C. \& Campling, R. C. (1962). Nutr. Abstr. Rev. 32, 669.

Bryant, M. P. \& Robinson, I. M. (1961). Appl. Microbiol. 9, 96.

Davidson, J., Mathieson, J. \& Boyne, A. W. (1970). Analyst, Lond. 95, 181.

Henderson, C., Hobson, P. N. \& Summers, R. (1969). In Proceedings of Fourth International Symposium on the Continuous Cultivation of Micro-organisms, pp. 189-204. [1. Malik, editor]. Prague: Czeckoslovakia. London \& New York: Academic Press.

Hume, I. D., Moir, R. J. \& Somers, M. (1970). Aust. J. agric. Res. 21, 283.

Hungate, R. E. (1966). The Rumen and its Microbes. New York \& London: Academic Press.

Mehrez, A. Z. \& Ørskov, E. R. (1976). Proc. Nutr. Soc. 35, 40A.

Mehrez, A. Z. \& Ørskov, E. R. (1977). J. agric. Sci., Camb. 88, 645.

Miller, E. L. (1973). Proc. Nutr. Soc, 32, 79.

Ørskov, E. R., Fraser, C. \& McDonald, I. (1972). Br. J. Nutr. 27, 491.

Ørskov, E. R., Fraser, C. \& McDonald, I. (1974). Br. J. Nutr. 31, 89.

Ørskov, E. R., Smart, R. \& Mehrez, A. Z. (1974). J. agric. Sci., Camb. 83, 299.

Satter, L. D. \& Slyter, L. L. (1974). Br. J. Nutr. 32, 199.

Whitehead, R., Cooke, G. H. \& Chapman, B. T. (1967). Automation in Analytical Chemistry, Technicon Symposium, vol. 2, p. 377. Basingstoke, Hants: Technicon Instruments Co. Ltd. 